УДК 321.01:14

DOI https://doi.org/10.32838/TNU-2663-5941/2020.3-2/18

Мигаль В.П.

Національний аерокосмічний університет імені М.С. Жуковського «Харківський авіаційний інститут»

\title{
Сілевич В.Ю.
}

Національний аерокосмічний університет імені М.Є. Жуковського «Харківський авіаційний інститут»

Мигаль Г. В.

Національний аерокосмічний університет імені М.Є. Жуковського «Харківський авіаційний інститут»

\section{ІНТЕГРАЛЬНА ДІАГНОСТИКА ФУНКЦІОНАЛЬНОГО СТАНУ ЕЛЕМЕНТІВ ТРАНСПОРТНИХ СИСТЕМ НА ОСНОВІ ВІЗУАЛІЗАЦІЇ ШУМОВИХ СИГНАЛІВ}

Сьогодні актуальним є розроблення систем он-лайн оцінки функціонального стану транспортних систем (ТС) (автомобільного двигуна, реактивного двигуна і т.n.) для он-лайн ідентифікації порумень. Зокрема, вібраційні та звукові сигнали, щзо випромінюються механічними системами пориневого двигуна, є джерелами інформаиії, які можуть слугувати для визначення його стану. Однак існують проблеми з різноманіттям, неоднозначністю, нелінійністю, багаторозмірністю інформаційних потоків від динамічних систем, які обмежують можливості інформаційних технологій. Одним із шляхів подолання ичих проблем є візуалізація даних із застосуванням методів комп'ютерної когнітивної графіки. Показано, щуо виявити індивідуальні особливості структури сигналів різної природи дозволяє їх представлення у вигляді 3D-моделей в просторі динамічних подій. Найбільш перспективною є параметрична візуалізація шумового акустичного сигналу транспортних засобів, яку можна здійснити за допомогою міждисциилінарного підходу до виявлення індивідуальності функціонування складних систем. В основі підходу - параметричне представлення інформаційного сигналу об' скта (електричного сигналу, звуку, иуму тощо) у просторі ймовірних динамічних подій. На прикладі трансформації шуму сенсорів транспортних засобів, а також шуму поршневих двигунів із диференціацією за режимом роботи і задіяних допоміжних агрегатах в топологічну 3D-модель показані особливості візуалізації у параметричному просторі ймовірних динамічних подій циифрованого шумового сигналу автомобільного двигуна. Показано, щуо обробка та візуалізація акустичного сигналу за допомогою перетворення у топологічну 3D-модель відкриває нові можливості створення методів дистанційного моніторингу механічних систем із можливістю аналізування стану і ресурсу об'єкта, щзо випромінює звук, і раннього виявлення потениійних відмов.

Ключові слова: двигун внутрішнього згоряння, транспортна система, шум, інтелектуальні системи, дистанційна діагностика, дефекти двигуна, сигнатури, параметричний простір, просторово-часова структура сигналу.

Постановка проблеми. Нові стандарти безпеки зумовили зростання складності всіх елементів автомобілів, що призвело до різкого збільшення джерел інформації для забезпечення їх надійності (сенсорів різної природи). Посилення вимог до їх надійності та безпечної експлуатації потребує пошуку нових можливостей контролю людино-машинної взаємодії. Зокрема, використати унікальний біосенсор, яким є слух людини. Адже він давно використовується в медицині, матеріалознавстві і інших областях техніки.
Сьогодні актуальною є розробка інтелектуальних систем оцінювання функціонального стану елементів транспортних систем (ТС) (автомобільного двигуна, реактивного двигуна і т.п.) для їх он-лайн моніторингу. Однак різноманіття джерел інформації різної природи і призначення (сенсорів, датчиків і т.п.), а також контролерів обмежує можливості оптимальної експлуатації ТС. Ключова проблема - у збільшенні різноманіття інформаційних потоків від елементів динамічних систем, а також їх нелінійність, багато розмірність i неоднозначність. Усе це обмежує можливості 
інформаційних технологій. Однак шуми різної природи, що випромінюються різними елементами механічних систем (поршневого двигуна, коробки і т.п.), притаманні всім джерелам інформації. Тому вони можуть слугувати джерелами інформації під час визначення функціонального стану елементів ТС.

Аналіз останніх досліджень і публікацій. Зазначимо, що аналіз акустичної емісії, який породжує робота механізмів і агрегатів механічних систем, досить широко використовується для діагностики дефектів різної природи. Ординарні можливості способу визначення несправностей за допомогою конкретних датчиків (температури, тиску, положення частин агрегатів, що обертаються та ін.), які встановлено на двигуні автомобіля та його агрегатах, зводяться до аналізу інформації про параметри роботи агрегатів і систем. Серед них можна виокремити найбільш значущі:

- вихід із ладу механізму привода газорозподільної системи за допомогою датчиків Холла, що встановлено на колінчастому і розподільному валі;

- засмічення повітряного фільтра або розгерметизація повітропроводів двигуна за допомогою датчика визначення величини розрідження задросельного простору (тільки для бензинових двигунів);

- пошкодження роботи системи охолодження за допомогою датчика температури двигуна;

- пошкодження змащувальної системи двигуна за допомогою датчика тиску мастила.

Інформація про несправність 3 'являється або в результаті обробки сигналів датчиків і порівнянні їі з певною базовою величиною або в разі відсутності сигналу 3 датчика. У більшій кількості випадків вихід із ладу агрегату відбувається поступово. Як приклад можна привести процес розтягування металевого ланцюга привода газорозподільного механізму: спочатку, при невеликому розтягненні, під час запуску двигуна, відбуваються коливання ненатягненого ланцюга, що супроводжується появою шумового акустичного сигналу певної тональності. Коли масляна система набирає необхідний тиск, ланцюг натягується і шум зникає. Під час подальшого його розтягування тривалість сигналу збільшується і нарешті відбувається проковзування зуба зірки цепу i асинхронність обертання колінчастого i розподільного валу призводить до виходу з ладу системи газорозподілення. Аналіз акустичного сигналу роботи двигуна можна використовувати для визначення стану авіаційного повітряно-реактивного двигуна для попередження відмов у його роботі. Наприклад, у роботі [1] за допомогою аналізу звукового сигналу під час роботи повітряно-реактивного двигуна проводилися дослідження із вивчення нестабільності горіння, вібрацій та термоакустичних коливань для отримання механізму відмов агрегатів. Зокрема, в роботі [2, с. 291-299] велися дослідження механізму виходу з ладу кулькового підшипника. Кореляційний аналіз результатів проведених досліджень дозволив встановити залежність між ступенем деградації підшипника і шумом його роботи.

Вивченню шуму агрегатів системи охолодження і змащування двигуна приділяється значно більше уваги. Зношення крильчатки відцентрового насосу супроводжується підвищенням шуму в роботі двигуна [3, с. 509-514], i, таким чином, за допомогою аналізу акустичної емісії можна чітко виявити ступінь деградації крильчатки. Таким же чином в роботі [4] відстежується зміна шуму двигуна при різних умовах змащення циліндропоршневої групи. Для аналізу шуму використовувалося віконне перетворення Фур'є. Порівняння результатів обробки акустичного сигналу двигуна за допомогою перетворення Фур' $є$ або вейвлетами було зроблено в роботі [5, с. 1807-1826]. Головним висновком роботи було те, що перетворення сигналу базовими функціями (вейвлетами або гармонічним сигналом) не показує енергетичну складову сигналу, що досліджується.

У роботі [6, с. 295-298] проводилися експериментальні дослідження шуму поршневого двигуна 3 метою виявлення його несправностей. Під час проведення експериментів оброблялися сигнали нормально працюючого двигуна на різних швидкостях обертання і з різною кількістю працюючих циліндрів. У фокусі дослідження лежало порівняння максимальних амплітуд звукових сигналів.

У статті [7, с. 1005-1009] проводився аналіз звуку двигуна 3 метою виявлення його несправностей. Експеримент проводився для бензинового двигуна в трьох станах: робота циліндрів із перебоями на холостому ході, робота 3 пропусками запалювання і робота двигуна без відбору потужності. Під час оброблення сигналу враховувалися наступні параметри: основна частота звуку, частотний спектр, енергія звукової хвилі, швидкість переходу через нуль. Для обробки використовувалися методи математичної статистики, які дали прийнятний результат для розрізнення різних режимів роботи двигуна.

Однак методи інтегрального перетворення (вейвлет та Фурь'є аналіз) не дозволяють отримати інформацію про зміну величин швидкості та прискорення амплітуди сигналу, які проявляють 
себе при порушеннях роботи механічних систем. Проведення диференціювання сигналу із визначенням першої та другої похідної дозволяє отримати якісну і кількісну характеристику роботи механічної системи, яка несе інформацію про стан механізму, що досліджується [8, с. 170-175; 9, с. 354-358]. Використання зазначених засобів на додаток до штатної системи діагностування несправностей двигуна, можливості якої обмежені використанням цільових датчиків системи моніторингу, може значно розширити можливості оцінювання стану для механічних систем і вивести iii на новий якісний рівень 3 можливістю поглибленого аналізу роботи двигуна. Зовнішні та внутрішні чинники впливають на циклічні процеси в складних ТС. Взаємозв'язки між ними знаходять своє відображення в динамічній структурі інформаційних сигналів різної природи (електричного сигналу, звуку, шуму тощо). У ній поряд 3 періодичними складовими співіснують і хаотичні, що обумовлює нестаціонарність сигналів. При цьому характер взаємозв'язку хаотичних і періодичних складових обумовлює як індивідуальні особливості динаміки кожного циклу, так і статистичні особливості їх сукупності. Вони взаємопов'язані, і тому складні системи (організм людини, двигун, сенсор тощо) як об’єкт дослідження є нелінійною динамічною системою.

Для онлайн-ідентифікації функціонального стану елементів ТС перевагу мають шумові компоненти сигналів різної природи, які мають набагато більшу інформативність, ніж інші. Шум має випадковий та фрактальний характер, відповідно, методи його аналізу використовують статистичні характеристики, що дозволяє характеризувати стійкі порушення в роботі механізмів. Також це дає можливість виявити тонкі приховані закономірності в роботі механізму, що дозволяє забезпечити ранню ідентифікацію негативних змін у роботі.

Постановка завдання. Таким чином, метою роботи є створення методу визначення механічних дефектів за шумовими параметрами об'єкта. Це може допомогти визначати відмінності в роботі поршневого двигуна, наприклад, ще до його виходу 3 ладу, або допомагати здійснювати моніторинг роботи досліджуваного агрегату 3 метою формування інформації про ресурс агрегату, нештатної його роботи і т.п. Завданням роботи було дослідження звуку поршневого двигуна та його агрегатів за допомогою диференціювання акустичного сигналу його роботи.

Виклад основного матеріалу дослідження. Найбільш перспективною $€$ параметрична візуалізація шумового сигналу ДС, яку можна здійснити за допомогою міждисциплінарного підходу до виявлення індивідуальності функціонування складних систем [9, с. 354-358; 10, с. 387-391, 11, с. 2-3]. В основі підходу - параметричне представлення інформаційного сигналу об'єкта (електричного сигналу, звуку, шуму тощо) у просторі ймовірних динамічних подій. У ньому індивідуальні характеристичні ознаки структури будьякого інформаційного сигналу проявляються під час перетворення його в топологічну 3D-модель, яка $€$ замкнутою траєкторією простору динамічних подій. Така геометризація інформаційного потоку супроводжується просторово-часовою декомпозицією на упорядковані та взаємопов'язані складові. Геометрично вони відрізняються крутизною чи кривизною, а фізично - швидкістю чи прискоренням динамічних подій $[9$, с. 354-358; 10, с. 387-391; 11, c. $2 ; 12$, с. 134-144]. Просторово-часова впорядкованість складових найбільше проявляється в ортогональних проекціях траєкторії, конфігурації яких $є$ індивідуальними графічними образами-сигнатурами джерела інформації 1-го і 2-го порядків. Вони є природними паттернами просторово-часової структури сигналу, що надає можливість ї порівнювати та швидко ідентифікувати зміну стану об'єкта [11, с. 2-3; 12, с. 134-144].

Об'скт дослідження. Поршневий двигун внутрішнього згоряння (ПДВЗ), в процесі своєї роботи є джерелом різних звукових коливань, які випромінюються починаючи від руху газів (впуск повітря і випуск відпрацьованих газів), механічної взаємодії зубчастих і кулачкових механізмів і закінчуючи шумом додаткових агрегатів двигуна (вентилятор охолодження, насос високого тиску i т. і.). Також за звуком підвіски автомобіля під час їзди досвідчені механіки можуть визначити не тільки характер несправності, але і конкретне місце установки дефектного агрегату. Оскільки ПДВ3 є пристроєм з великою кількістю підсистем, то робота кожної такої системи буде супроводжуватися генерацією звуку певної тональності частоти і фази. Оскільки швидкість поширення звуку має певну величину, що залежить від середовища, в якій вона поширюється, то також можна визначити, при наявності звукових сенсорів встановлених в чотирьох різних точках, джерело сигналу. Створення методу визначення механічних несправностей об'єкта за звуковою картиною допоможе визначати відмінності в роботі поршневого двигуна ще до виходу агрегату з ладу або допомагати діагностичній системі здійснювати моніторинг роботи звукогенеруючого агрегату 3 
метою формування інформації про його ресурс, позаштатну роботу і т. i.

Дослідження акустичного сигналу двигуна. Диференціювання акустичного сигналу із отриманням першої та другої похідної дозволяє отримати інформацію про швидкість та прискорення амплітуди сигналу. Так, у просторі «стан швидкість - прискорення» кожну динамічну подію можна відобразити точкою 3 координатами $\mathrm{X}(\mathrm{t}), \mathrm{dX}(\mathrm{t}) / \mathrm{dt}, \mathrm{d}^{2} \mathrm{X}(\mathrm{t}) / \mathrm{dt}^{2}$. Причинно-наслідково пов'язані між собою події утворюють в просторі «стан-швидкість-прискорення» замкнену траєкторію $[9$, с. $354-358 ; 10$, с. $387-391 ; 11$, с. $2-3$; 12 , с. 134-144].

Застосування чисельного диференціювання відцифрованих сигналів має місце при обробці аналітичної інформації. Перша похідна сигналу характеризує швидкість зміни амплітуди щодо зміни абсциси, тобто осі часу, яка інтерпретується як нахил дотичної лінії сигналу в кожній точці. Друга похідна $\epsilon$ похідною від першої і являє собою міру кривизни лінії сигналу, або швидкість зміни кута нахилу дотичної сигналу в кожній точці кривої.

Для отримання інформації про відхилення від нормальної роботи механічної системи необхідно мати еталонний звук працюючого двигуна i дефектний. Запис звуку проводився на мікрофон 3 діапазоном частот сприйняття 60-18000 Гц, iз частотою дискретизації 44100 Гц в форматі WAV. Подальша обробка звуку та побудова графічних картин проводилася в додатку Matlab.
Так, у першому випадку (див. рис. 1) розглядається поршневий трициліндровий бензиновий двигун із нормально працюючими системами (рис. 1, a) і такий же двигун, але у якого $є$ пошкодження, що викликають зміни звуку роботи двигуна - тріщина в випускному колекторі (рис. 1, б). На рисунку 1 в координатах у - dy / dt представлено результати обробки запису звукового сигналу поршневого двигуна внутрішнього згоряння, які відображають статичні і динамічні параметри системи 3 особливостями циклу. Як видно з отриманих зображень, зміна сигналу призвела не тільки до зміни масштабу картини, а й до трансформації вигляду геометричної фігури, утвореною безліччю аналізованих точок. Також на рисунку проявляються артефакти у вигляді групи точок зліва від основного скупчення вздовж осі стану.

На зміну характеристик звукового сигналу впливають також режими роботи двигуна, його стан і робота додаткових агрегатів. Розглянемо особливості акустичного стану на 4-х циліндровому двигуні, коли всі агрегати нормально працюють, а відмова є в одній із підсистем двигуна - системі запалювання. Так, на рис. 2 показано діаграму стану нормально працюючого 4-х циліндрового двигуна, нагрітого до робочої температури в координатах $\mathrm{dy} / \mathrm{dt}-\mathrm{d}^{2} \mathrm{y} / \mathrm{dt}^{2}$ (рис. 2, a), та діаграма стану 4-х циліндрового ДВ3 з однією відключеною свічкою запалювання (рис. 2, б) і $з$ двома відключеним свічками запалювання (рис. 2, в).

До несправностей роботи двигуна можуть приводити відмови в роботі певних агрегатів і систем.

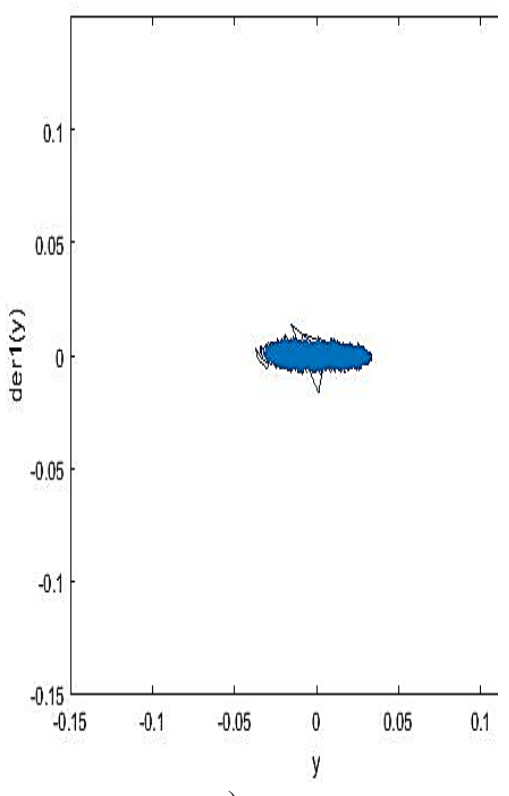

a)

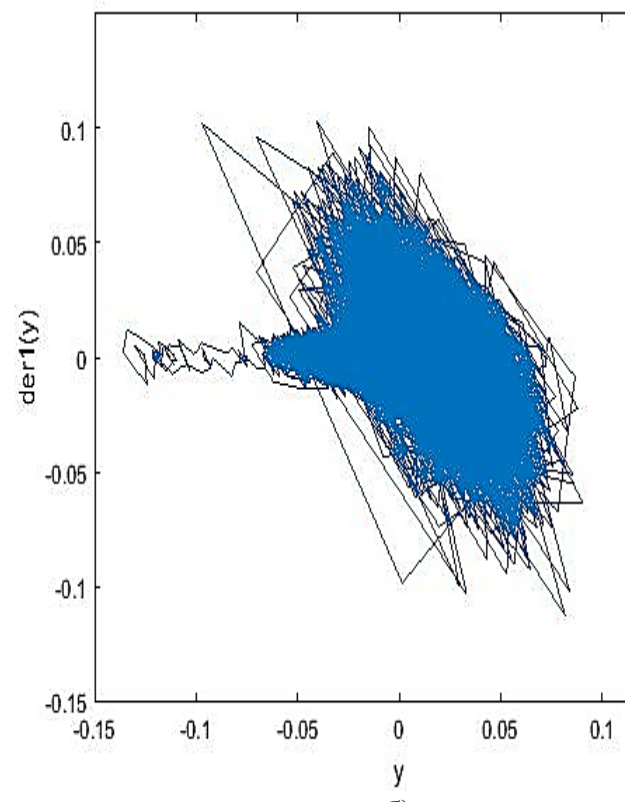

б)

Рис. 1. Подання акустичного шуму 3-х циліндрового ПДВЗ

3 нормально працюючими агрегатами (а) та 3 дефектом у випускному колекторі (б) в координатах y - dy/dt 


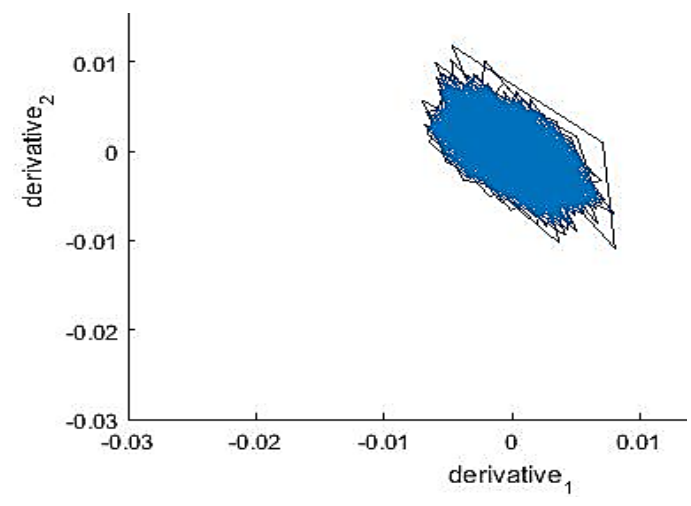

a)

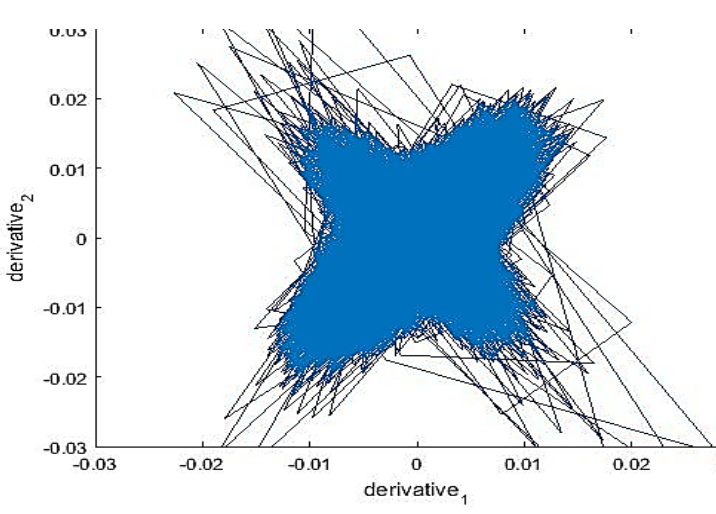

б)

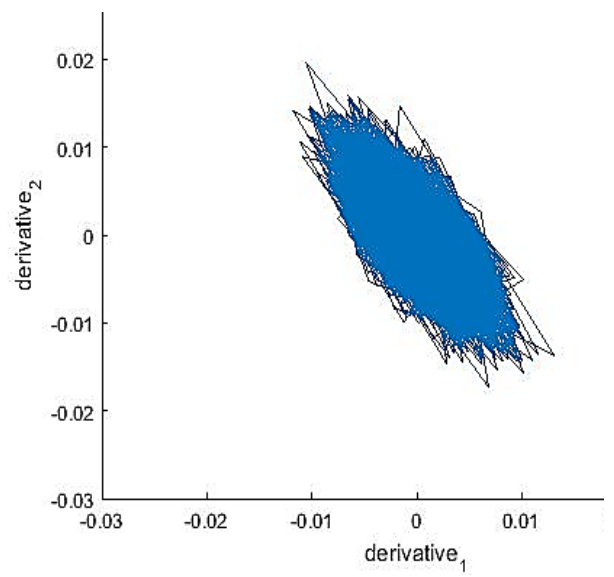

B)

Рис. 2. Подання акустичного шуму 4-х циліндрового бездефектного ДВ3 (а), ДВЗ з однісю відключеною свічкою запалювання (б) та ДВ3, що працює на двох із чотирьох свічок запалювання (в) в координатах $\mathrm{dy} / \mathrm{dt}-\mathrm{d}^{2} \mathrm{y} / \mathrm{dt}^{2}$

Робота механічних систем супроводжується генерацією звукових коливань певної тональності, частоти, амплітуди і фази, і якщо порушується режим роботи додаткового пристрою, або агрегат перестає працювати взагалі, це, безумовно, викличе зміни першої і другої похідної в загальному шумі двигуна.

Відключення свічки запалювання не дозволяє паливо-повітряної суміші в циліндрі згоріти $\mathrm{i}$, отже, поршень не може здійснити робочий хід під час розширення вихлопних газів. Із рисунків видно, що, окрім зміни масштабу картини по всіх осях, яке можна віднести до кількісної характеристики, відбувається і зміна форми фігури, що відноситься до якісної характеристики.

Робота додаткових пристроїв також супроводжується генерацією акустичних сигналів, зміну яких можна відстежити на загальній звуковій картині. На рис. 3 показана нормальна робота 4-х циліндрового ДВЗ (а) і робота двигуна з відключеним приводом компресора кондиціонера, гідро- підсилювача керма, помпи системи охолодження i генератора (б) в координатах у $-\mathrm{d}^{2} \mathrm{y} / \mathrm{dt}^{2}$.

Під час детального розгляду видно, що в порівнянні із базовим шумом зміни торкнулися масштабу фігури вздовж осі абсцис і з'явилися артефакти справа від основної маси точок. Окрім того, на рисунку значно збільшилася кількість випадкових точок навколо основної фігури. Зміни також торкнулися і положення фігури - на рисунку (a) вісь симетрії вздовж фігури має певний кут нахилу відносно горизонтальної осі, а на рисунку (б) кут нахилу горизонтальної осі симетрії фігури не відстежується.

Висновки. Обробка та параметрична візуалізація акустичного сигналу за допомогою його перетворення у 3D-топологічну модель відкриває можливості створення методу дистанційного моніторингу механічних систем 3 можливістю раннього виявлення функціонального стану агрегатів, збоїв у їх функціонуванні та прогнозування ресурсу елементів механічної системи. 


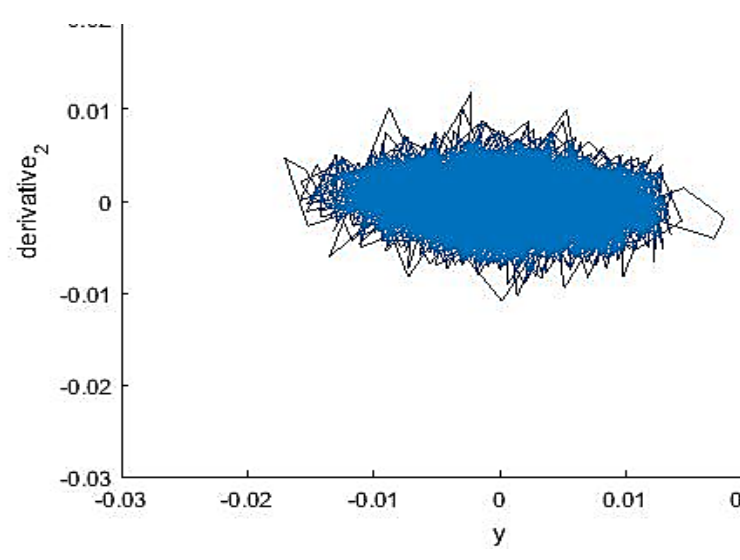

a)

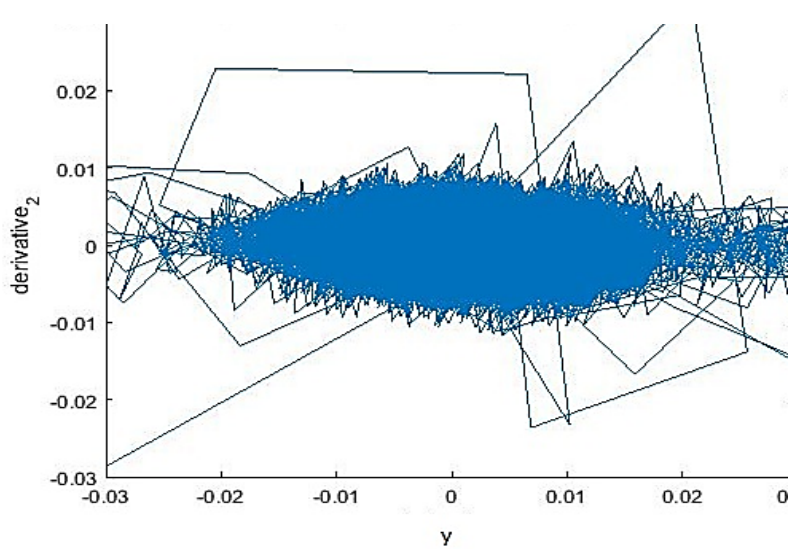

б)

Рис. 3. Подання шуму двигунів у координатах $y-d^{2} y / d t^{2}$

Створення інформаційної системи на базі смартфону для онлайн-діагностики функціонального стану двигуна дозволяє значно спростити експлуатацію автомобіля користувачу-непрофесіоналу, забезпечити дистанційний моніторинг та своєчасне виявлення несправностей автомобіля.

Наведена обробка шумових сигналів функціонуючої механічної системи дає передумову до створення методу дистанційної діагностики елементів ТС 3 можливістю визначення: збоїв у функціонуванні об'єктів, що генерують звук; стану агрегатів і систем; ресурсу елементів механічної системи; наявності дефектів і механічних пошкоджень деталей і агрегатів. Крім того, особливе значення це може мати для аналізу екологічного (шумового і хімічного) впливу ДВЗ на навколишнє середовище, адже, наприклад, під час використання неякісного пального або некоректної роботи паливної системи або системи запалювання відбувається погіршення умов згоряння паливо-повітряної суміші, в результаті чого зміниться звук роботи двигуна, що обов'язково стане поміченим такою системою звукового аналізування. Отже, система оцінювання якості моніторингових показників на додаток до штатної системи діагностики несправностей двигуна, можливості якої обмежені використанням цільових датчиків, може значно розширити діагностичні можливості для механічної системи i вивести їі на новий якісний рівень із можливістю поглибленого безперервного аналізу стану двигуна.

\section{Список літератури:}

1. Keshav Sharma, Armaan Aditya, G.Srinivas. Material failure analysis and engine combustion instabilities of both air and non-air breathing engines/ Materialstoday:Proceedings, 2019. DOI: 10.1016/j.matpr.2019. 10.105.

2. Hyunseok Oh, Michael H.Azarian, Carlos Morillo, Michael Pecht, Edward Rhem. Failure mechanisms of ball bearings under lightly loaded, non-accelerated usage conditions. Tribology International, 2015. № 81, pp. 291-299. DOI: 10.1016/j.triboint.2014.09.014.

3. Alsadak Daraz, Samir Alabied, Fengshou Gu, Andrew D. Ball . Modulation Signal Bispectrum Analysis of Acoustic Signals for the Impeller Wear Detection of Centrifugal Pumps. 25th International Conference on Automation and Computing (ICAC), 2019, pp. 509-514. DOI:10.23919/IConAC.2019.8895023.

4. Nasha Wei, James Xi Gu, Fengshou Gu, Zhi Chen, Guoxing Li, Tie Wang, Andrew D. Ball. An Investigation into the Acoustic Emissions of Internal Combustion Engines with Modelling and Wavelet Package Analysis for Monitoring Lubrication Conditions. Energies, № 12(4)-640, 2019. DOI:10.3390/en12040640.

5. Ghaderi, H., Kabiri, P. Automobile engine condition monitoring using sound emission. Turkish Journal of Electrical Engineering \& Computer Sciences, № 25, 2017. pp.1807-1826. DOI: 10.3906/elk-1605-77.

6. Wail, M. Adaileh. Engine Fault Diagnosis Using Acoustic Signals. Progress in Environmental Protection and Processing of Resource, 2013. pp. 295-298. DOI: 10.4028/www.scientific.net/AMM.295-298.2013.

7. Chomphan, S., Kingrattanaset, Th. An analysis of sound for fault engine. American Journal of Applied Sciences, 2014. № 11(6), pp. 1005-1009. DOI: 10.3844/ajassp.2014.1005.1009.

8. Сілевич В.Ю. Аналіз стану поршневого двигуна та його агрегатів за акустичним сигналом їх роботи. Вчені записки Таврійського національного університету ім. В.І. Вернадського, 2019. № 30(69). № 6. C. 170-175. DOI: 10.32838/2663-5941/2019.6-2/30. 
9. Мигаль В.П., Мигаль Г.В. Киберфизический подход к исследованию функционирования динамических систем. Электротехнические и компьютерные системы, 2016. № 22(98). С. 354-358.

10. Mygal V.P., But A.V., Mygal G.V., Klimenko I.A.. An interdisciplinary approach to study individuality in biological and physical systems functioning. Scientific Reports, Nature Publishing Group, 2016, № 6. P. 387-391. DOI: $10.1038 /$ srep29512.

11. Mygal V.P., Mygal G.V. Visualization of Signal Structure Showing Element Functioning in Complex Dynamic Systems - Cognitive Aspects. Journal of nano- and electronic physics, 2019. Vol. 11, No 2, 02013. P. 1-4. DOI: 10.21272/jnep.11(2).02013.

12. Mygal V, Mygal G. Problems of Digitized Information Flow Analysis: Cognitive Aspects. Information \& Security: An International Journal. 2019. 43. № 2, pp. 134-144. DOI: 10.11610/isij.4312.

\section{Mygal V.P., Silevytch V.Yu., Mygal G.V. INTEGRATED DIAGNOSTICS OF THE FUNCTIONAL STATE OF THE ELEMENTS OF TRANSPORT SYSTEMS BASED ON VISUALIZATION OF THE NOISE SIGNAL}

Today, it is urgent to develop systems for on-line assessment of the functional state of transport systems (automobile engine, jet engine, etc.) for quick and timely identification of violations. In particular, vibration and sound signals emitted by mechanical systems of a reciprocating engine are sources of information that can serve to determine its state. However, there are problems with diversity, ambiguity, nonlinearity, multidimensionality of information flows from dynamic systems that limit the capabilities of information technologies. One way to overcome these problems is to visualize data using computer cognitive graphics techniques. It is shown that the individual characteristics of the structure of signals of various nature can be identified by their representation in the form of $3 D$ models in the space of dynamic events. The most promising is the parametric visualization of the noise signal of transport systems. It can be implemented using an interdisciplinary approach to identify the individual functioning of complex systems. The approach is based on the parametric representation of the information signal of an object (electrical signal, sound, noise, etc.) in the space of probable dynamic events. By the example of transformation of the noise of the sensors of transport systems, as well as the noise of various engines into a topological $3 D$ model, the visualization features of the possible dynamic events of the digital noise signal of a car engine are shown in the parametric space. It is shown that processing and visualization of an acoustic signal by converting to a $3 D$ topological model opens up new possibilities for creating methods for remote monitoring of mechanical systems with the possibility of early detection of potential failures.

Key words: internal combustion engine, noise, intelligent systems, remote diagnostics, engine defects, signatures, parametric space, spatio-temporal signal structure. 